looked upon as an absolute contra-indication to the operation. As long as the opening in the parietes is suitable the size of the sac need not be taken into consideration.

The operation.--The method has been practised upon 21 patients. The procedure does not occupy more than a couple of minutes in the accomplishment and the after-treatment is of the most simple description. The preliminary treatment consists in a thorough evacuation of the bowels and the reduction of flatulence by suitable dietary before operation. A few simple instruments are required in the shape of a knife, dissecting forceps, and a blunt dissector. The essential material is a piece of elastic cord one-eighth of an inch in diameter and about 3 inches long. The actual technique of the operation is as follows: The skin over the fundus of the protrusion is grasped with a pair of dissecting forceps, and skin and sac are pulled gently upwards from the abdominal wall. Great care is exercised in ascertaining that the contents of the sac are completely reduced. Three small incisions are made at equal intervals around the periphery of the sac, at the point where the skin is reflected on to the abdominal wall. (Fig. 1.) These incisions penetrate the

FIG. 1.

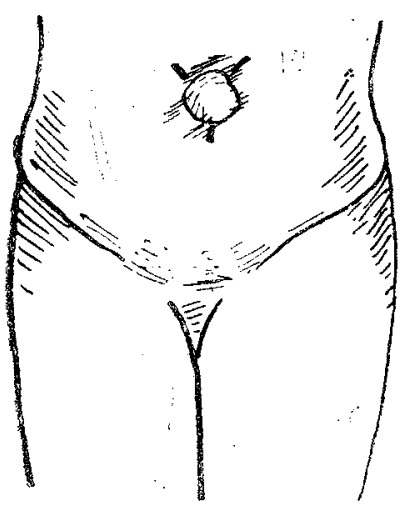

FIG. 1.-Showing radiating skin incisions round the hernia FIG. 2.- Second stage of the operation. The elastic ligature is lying in position. In practice it lies more closely round the pedicle of the sac.

skin and subcutaneous tissues, but they must not injure the sac. With a blunt dissector it is now possible to undermine the tissues around the pedicle of the sac-the three radiatory incisions facilitate the performance of this. The elastic ligature is now pulled beneath the skin, following the track of separation. (Fig. 2) This is most conveniently done by means of an artery forceps, which pulls the ligature from one incision to another around the periphery. When the ligature is in position the operator, having satisfied himself that the sac is empty, pulls the ligature as tightly as possible around the pedicle of the sac and fastens it so with a stout piece of silk. The ends of the elastic ligature are left protruding through one of the incisions, and they are cut to a convenient length; a simple dressing is applied and kept in position by means of a band of adhesive plaster.

After-treatment. - The ligature is allowed to remain in position for six days and then removed by cutting the silk knot. The opening which it leaves quickly closes. This early removal of the ligature differs from the method employed by Nota, of Turin, as described by Brun. Nota does not remove the ligature but allows it to slough out, which it does usually about the twelfth day. An early removal is to be preferred; it does in no way jeopardise the ultimate result, and it is a much more aseptic proceeding. A dressing is worn until the wounds are healed. No further application is made.

Result.-One can only say that the results have been uniformly successful. The first case operated on was one which demonstrated the permanency of the cure. About two days after operation the child developed whoopingcough, but in spite of persistent coughing and straining there was no recurrence of the protrusion.

Advantages of the operation.-These may be summarised as follows. 1. The operation is essentially of the most simple type. 2. The a ter-treatment is brief and satisfactory. 3 . The cure is apparently a permanent one.

Edinburgh.

UNIVERSTTY of LeEDS.-The address at the opening of the next session of the School of Medicine will be given on Oct. 1st by Professor C. S. Sherrington.

\section{A NOTE ON HELMINTHIASIS IN BASSA PROVINCE, NORTHERN NIGERIA.}

\section{BY J. E. L. JOHNSTON, M.B., B.S. LOND., D.T.M. \& H. CantaB.} WEST AFRICAN MEDICAL STAFF.

Bassa Province is situated in the south-east corner of Northern Nigeria, bordering on Southern Nigeria to the south, bounded on the west by the river Niger, on the north by the river Benue, and on the east by Muri Province. Almost the whole province is characterised by extremely thick lurimi, or bush, in many places so dense as to be practically impenetrable, and it is intersected by several small rivers and streams, the most important being the Amara, the Uge, the Urito, the Okura, and the Mabolo. The resulting climate is therefore, on the whole, damp and equable. For 1909 and 1910 the maximum relative humidity was 85 and 86 respectively, the minimum 67 and 64 ; during the early part of this year-when the following observations were made-the rainfall was much below the average, and the relative humidity fell on one occasion to 18 . The mean maximum temperature for the year is as a rule about $90^{\circ} \mathrm{F}$., the mean minimum about $63^{\circ}$.

The people. - The natives consist mainly of pagan tribes, Igarras, Ndomas, and Bassa Comos, but there are several smaller tribes and some isolated communities of Mohamedan Hausas from the north. Ankpa, the chief European station, is in the midst of the Igarras. While I was stationed in the province some few of the prisoners exhibited symptoms of anæmia and debility, associated in some cases with œdema of the feet and legs, and even ascites, and with indefinable

TABLE I. - Showing the Ova fownd in 30 Cases.

\begin{tabular}{|c|c|c|c|}
\hline No. & Tribe. & Ova found. & Remarks. \\
\hline 1 & Bassenge. & Niv. & - \\
\hline 2 & $"$ & Ankylostomum. & Health good. \\
\hline 3 & Igarra. & Nil. & - \\
\hline 4 & 壮 & Trichuris trichiura. & - \\
\hline 5 & 9 & $\begin{array}{l}\text { Ankylostomum ; } \\
\text { ascaris. }\end{array}$ & Health good. \\
\hline 6 & $"$ & Nill. & - \\
\hline 7 & " & , & - \\
\hline 8 & 3 & $\begin{array}{l}\text { Ankylostomum ; } \\
\text { ascaris. }\end{array}$ & $\begin{array}{l}\text { Had a slight attack of amwic } \\
\text { dysentery; health otherwise } \\
\text { good. }\end{array}$ \\
\hline 9 & 39 & $\begin{array}{l}\text { Ankylostomum ; } \\
\text { ascaris. }\end{array}$ & $\begin{array}{c}\text { "Craw-craw." General health } \\
\text { good. }\end{array}$ \\
\hline 10 & 9 & Nil. & - \\
\hline 11 & , & ", & - \\
\hline 12 & " & , & - \\
\hline 13 & 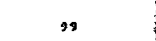 & 9 & - \\
\hline 14 & , & Ankylostomum. & Health good. \\
\hline 15 & , & " & Health fair. \\
\hline 16 & Okpoto & ", & Edema of feet anḋ egs. \\
\hline 17 & 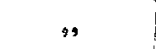 & Tænia solium. & - \\
\hline 18 & $s$ & Ankylostomum. & $\begin{array}{l}\text { Pains in legs, odema, and } \\
\text { hyperæsthesia over tibiæ. }\end{array}$ \\
\hline 19 & " & $\begin{array}{c}\text { Ankylostomum; } \\
\text { ascaris ; } \\
\text { trichuris trichiura. }\end{array}$ & $\begin{array}{l}\text { Intense cdema, ascites, cardiac } \\
\text { failure, death. }\end{array}$ \\
\hline 20 & s & Ankylostomum. & $\begin{array}{l}\text { Health fair, but some slight } \\
\text { cedema of feet. }\end{array}$ \\
\hline 21 & Agatu. & Níl. & - \\
\hline 22 & $"$ &. & - \\
\hline 23 & Yoruba. & $\begin{array}{l}\text { Ankylostomum ; } \\
\text { ascaris. }\end{array}$ & $\begin{array}{c}\text { "Uraw-craw." Edema of feet } \\
\text { and legs. }\end{array}$ \\
\hline 24 & ," & Tænia solium. & $-\quad--$ \\
\hline 25 & Hausa. & $\begin{array}{l}\text { Tænia solium; } \\
\text { ankylostomum. }\end{array}$ & Health good. \\
\hline 26 & " & Trichuris trichiura. & - \\
\hline 27 & , & Ankylostomum. & Health good. \\
\hline 28 & Beri-beri. & $\begin{array}{l}\text { Tænia solium ; } \\
\text { ascaris. }\end{array}$ & - \\
\hline 29 & Kakanda. & Ankylostomum. & Health good. \\
\hline 30 & Bagarini. & Nill. & - \\
\hline
\end{tabular}


pains in the joints and down the legs, and occasionally hyperæsthesia over the tibiæ. The signs in one or two cases seemed to point to beri-beri, in others to ankylostomiasis. However, the majority of the prisoners appeared to be in good health.

The stools. - I was led to examine the stools for helminthic infection, which $I$ did in 30 cases taken at random ('Table I.).

TABLE II.-Showing Results of Examination of the Blood.

\begin{tabular}{|c|c|c|c|c|c|c|c|}
\hline 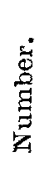 & 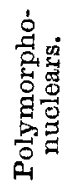 & 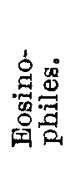 & 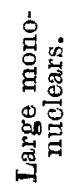 & 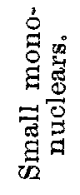 & 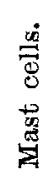 & 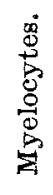 & $\begin{array}{l}\dot{0}: \dot{3} \\
8 \\
8 \\
8\end{array}$ \\
\hline 2 & 24 & 36 & 4 & 36 & - & - & 60 \\
\hline 3 & 51 & 16 & 6 & 27 & - & - & 60 \\
\hline 4 & 57 & 4 & 1 & 38 & - & - & 50 \\
\hline 5 & 58 & 18 & 3 & 21 & - & - & 50 \\
\hline 6 & 54 & 9 & 6 & 30 & 1 & - & 70 \\
\hline 7 & 22 & 42 & 6 & 30 & - & - & 60 \\
\hline 8 & 32 & 35 & 5 & 28 & - & - & 60 \\
\hline 9 & 57 & 11 & 15 & 16 & - & 1 & 60 \\
\hline 10 & 31 & 40 & 7 & 22 & - & - & 65 \\
\hline 11 & 28 & 56 & 3 & 13 & - & - & 60 \\
\hline 12 & 42 & 30 & 1 & 27 & - & - & 70 \\
\hline 13 & 36 & 16 & 20 & 26 & - & 2 & 80 \\
\hline 14 & 62 & 6 & 8 & 25 & - & - & 60 \\
\hline 16 & 74 & 3 & 4 & 19 & - & - & 40 \\
\hline 17 & 43 & 28 & 7 & 22 & - & - & 70 \\
\hline 18 & 60 & 3 & 3 & 34 & - & - & 60 \\
\hline 21 & 46 & 12 & 6 & 34 & 2 & - & 60 \\
\hline 22 & 64 & 5 & 3 & 28 & - & - & 60 \\
\hline 23 & 47 & 19 & 6 & 27 & $\ldots$ & 1 & 60 \\
\hline 24 & 28 & 21 & 3 & 48 & - & - & 55 \\
\hline 25 & 57 & 16 & 7 & 18 & 2 & - & 60 \\
\hline 26 & 29 & 17 & 12 & 42 & - & - & - \\
\hline 27 & 30 & 30 & 10 & 28 & 1 & 1 & 70 \\
\hline 28 & 26 & 34 & 4 & 36 & - & - & 50 \\
\hline 29 & 44 & 15 & 11 & 28 & 2 & - & 60 \\
\hline 30 & 35 & 29 & 6 & 30 & - & - & 70 \\
\hline
\end{tabular}

In these 30 cases I found:-

Single infection in $12,40 \%$

Double , , $6,20 \%$

Triple infection in 1, 3.3\%

No infection ", $11,36.6 \%$

The ova found were as follows :-

Ankylostome (or necator) in $14,46.6 \%$ Tænia solium in 4, 13.3\%

Ascaris lumbricoides " $6,20 \%$ Trichuris trichiura in 3,10\%

Examination after the administration of anthelmintics proved the presence of both ankylostome and necator. Table I. shows the results in more detail.

The blood.-I then proceeded to examine the blood of the same cases, except of four who were not available. The most noticeable feature was eosinophilia, which was present in almost every case (see Table II.), rising in one case as high as 56 per cent. This was seen not only in cases with ankylostome infection, but with other helminths, T. solium, ascaris, T. trichiura.

In some cases I believe it was due to skin diseases, probably parasitic, collectively termed "craw-craw" by the patients. These lesions usually commence as exceedingly irritable papular eruptions, beginning on the thighs or scrotum, sometimes on the arms, often becoming pustular from scratching, and often spreading on to the trunk. Wyler ${ }^{1}$ suggests that the eruption on the thighs and buttocks is really the seat of infection with ankylostomes, owing to the native habit of squatting on the ground.

In other cases the eosinophilia had no obvious cause, but I believe further search in the stools might have shown ova. Many cases showed great relative increase in the lymphocytes, possibly attributable to a preceding infection with malaria. Two cases showed malarial parasites, and two

1 Some Observations on Ankylostoma Infection in the Udi District of the Central Province, Southern Nigeria, by E. J. Wrler, Journal of Tropical Medicine and Hygiene, July lst, 1913.

showed microfilariae-one M. bancrofti, the other loa loa and M. perstans.

A rough hæmoglobin estimation showed the following results (see Table II.) :-

$$
\begin{aligned}
& 1 \text { had } 40 \% \text { hamoglobin. } \\
& 3,50 \% \\
& 1,55 \%
\end{aligned}
$$$$
13,60 \%
$$

The case showing only 40 per cent. had a large abscess in addition to ankylostome infection.

Treatment.- The treatment first adopted was 6 drachms of the eucalyptus, castor oil, and chloroform mixture in the early morning, repeated after an hour and a half, the dowble dose being again given three days later. This seemed quite inefficient, and better results attended the administration of thymol in divided doses. As I was shortly afterwards transferred from the station I was unable to observe the effects of treatment on the general health of the patients.

Remarks. - The above observations, though limited to 30 cases, would serve to show the extreme prevalence of infection with ankylostomes amongst the Bassa pagans. The Hausas seemed to me to be much less affected, though this could not be observed amongst the prisoners, of whom very few were Hausas. One reason for their comparative immunity appears to be their use of deep cement-lined pits for defæcation, whereas the pagan tribes make use of the nearest convenient spot in the bush, thus providing the ankylostome ovum with its most favourable conditions for development.

Ankylostomiasis probably has a distinct bearing on the fact that Hausa carriers are able to carry heavier loads for far greater distances than can pagans. A remarkable point was the absence of symptoms in many cases that showed infection and even considerable anæmia. The men were able to do their ordinary work, which was certainly not as a rule heavy, without complaining even of shortness of breath ; in other words, infection with ankylostomes is not synonymous with ankylostomiasis.

Conran ${ }^{2}$ states that all his cases complained first of epigastric pain, but this was uncommon in my series; the earliest symptoms seemed to be dyspnoea and dizziness, especially in a bright light, and these were followed by pains in the legs, cedema, and the ordinary symptoms of ankylostomiasis. Several of these cases were extremely like cases of beri-beri, and in some of these ankylostome ova were not found till the second or even third examination, and after the administration of a mild purge. The diagnosis between these two diseases, usually said to be easy, may in actual practice be a matter of considerable difficulty.

The Medical Research Institute, Lagos, Southern Nigeria .

\section{SUPPURATING ENDOTHELIOMA OF MECKEL'S DIVERTICULUM SIMU. LATING APPENDICITIS.}

BY T. CARWARDINE, M.S. LoND., F.R.C.S. ENG., SURGEON TO THE BRISTOL ROYAL INFIRMARY.

MECKEL's diverticulum is very rarely found in mammals with the exception of man, but is constantly represented in certain birds. The London museums contain about 100 specimens from the human species, half of which were obtained from post-mortem examinations ; about one-third had caused obstruction during life; a few had caused intussusception; and only three were the seat of inflammation.

Very few cases of inflammation of Meckel's diverticulum are to be found in literature; those simulating appendicitis could be counted on the fingers of one hand; and the presence of a suppurating tumour resembling an abscess of the appendix seems to be unique. In other cases in which there has been inflammation this has been usually due to torsion, perforation, or the presence of foreign bodies.

A woman, aged 38, was admitted under my care in 1910 for supposed appendicitis. Following weakness of a few weeks' duration she had sudden sharp pain in the right

2 A Report on Ankylostomiasis in the North Nyasa District. by P. $\mathbf{C}$ Conran, Journal of Tropical Medicine and Hygiene, July 1st, 1913. 